\title{
THE MISSIONS OF THE SOLDIERS IN THE LIMES PROVINCES. FRUMENTARII IN DACIA
}

George Cupcea

\section{Misiuni ale soldaților în provinciile de limes. Frumentarii în Dacia}

Frumentarii sunt însărcinați cu cele mai delicate misiuni, ca şi ceilalți colegi ai lor din officium consularis, sau detaşaţi la castra peregrinorum. Singurul atribut unic şi special este această dublă subordonare. Chiar dacă sunt aleşi şi promovaţi de guvernator, sunt trimişi la Roma, pentru a se pregăti, o perioadă determinată de timp, în castra peregrinorum, unde vor activa sub autoritatea împăratului. În cadrul acestui stagiu pot fi delegați cu misiuni variate în numele împăratului, oficial sau nu, oriunde în Imperiu, apoi putând fi trimişi în provinciile de origine pentru a-şi continua serviciul militar. Continuă să facă parte din officium consularis, până ce sunt promovați sau lăsați la vatră. În acest timp, vor fi însărcinați, de către guvernator, cu misiuni de poliție locală, în provincie, alături de beneficiarii şi speculatores. Alții pot să rămână la Roma, unde să fie promovați în interiorul castra peregrinorum, uneori chiar la centurio frumentarius, ceea ce le va permite să revină în armata provincială direct centurioni. În cadrul legiunii, pot fi promovați, gradual, la beneficiarius, speculator, şi, rareori, la centurionatul legionar. Par a avea doar îndatoriri de natură militară, spre deosebire de ceilalţi colegi din officium, care au şi sarcini civile sau juridice. În Dacia sunt atestaţi cel puţin trei astfel de ofițeri, unii chiar cu cariere de succes, iar în restul Imperiului mai avem cel puțin patru, provenind din armata Daciei.

Key words: frumentarius, Dacia, castra peregrinorum, centurio, centurio frumentarius.

The matter of military intelligence and secret police in the Roman Empire has long been discussed, from different points of view, and regarding various aspects of the military organization. Accepting the fact that we are unable to trace any military intelligence agency centred in Rome, it is possible to identify, a unit based in the capital, which acted as an internal security agency throughout the Empire ${ }^{1}$. The headquarters of these special troops were located in a military district, on mount Caelius. In this eastern part of the city, a military fort, named castra peregrinorum ${ }^{2}$, was probably built in the time of emperor Trajan, or even earlier ${ }^{3}$. This fort was considered, as the name implies, a "foreigners camp"4, a depot of principales and centurions $^{5}$, which garrisoned every soldier or officer sent with a particular assignment to Rome, for their stay time in the capital. It also seems that the castra peregrinorum could be used as a central point for the despatch of officers sent in provinces with various tasks ${ }^{6}$. One thing is

\footnotetext{
${ }^{1}$ Austin, Rankov 1995, 136.

2 Austin, Rankov 1995, 136; Durry 1968, 25-26; LeBohec 1994, 23; Mann 1988, 149 (Amm. Marcellinus, XVI.12.66); Rankov 1990, 176

${ }^{3}$ Clauss 1973, 82.

${ }^{4}$ Austin, Rankov 1995, 136.

${ }^{5}$ Durry 1968, 26; Baillie-Reynolds 1923, 175-179.

${ }^{6}$ Baillie-Reynolds 1923, 168-169; Rankov 1990, 176. For a detailed archaeological depiction of castra peregrinorum, see also Baillie-Reynolds , Ashby 1923.
} 
positive, the fort was home for any peregrini soldiers, meaning provincial ones, different from urbani, which were definitely citizens and part of the Rome garrison ${ }^{7}$.

Part of the inhabitants of castra peregrinorum, besides the frumentarii and their officers, is made of other kind of principales or even centurions. An inscription from the time of Gallienus ${ }^{8}$ confirms the presence of centuriones deputati et supernumerarii alongside the frumentarii and other peregrini, in this fort. These two kinds of centurions, deputati and supernumerarii are probably part of their legions, sent to Rome with various tasks. It also indicates that they were supernumerary to the regular establishment of centurions for a legion? Other kind of military elements present at one time in the castra peregrina are other principales, the speculatores, which seem to have been the second largest body garrisoned here during their stay in Rome, and the unique cases of singulares, beneficiarii or even cornicularii ${ }^{10}$.

The major part of the inhabitants of this fort are the frumentarii. These "road-runners"11 travel throughout the Empire, on land or sea ${ }^{12}$. Their name would imply their former duties as grain providers for a unit, but, by the time of the Principate, their missions vary widely ${ }^{13}$.

Although it has been thought that only the legions of the north and western armies were providing these officiales ${ }^{14}$, epigraphical evidence indicates that, coming from every legion of the Empire, the frumentarii gather at the Capital, in a numerus frumentariorum ${ }^{15}$, an $a d-h o c$ military unit, organized in Rome for the emperor's personal use. The unit has its own internal hierarchy, with its own officers, as the optio, canalicularius, aedilis castrorum, and evidently, the centurio frumentarius, to which many of them were promoted during their stay in Rome ${ }^{16}$. Their primary leadership is ensured by the princeps peregrinorum ${ }^{17}$, a senior legionary centurion $^{18}$, assisted by the subprinceps peregrinorum ${ }^{19}$. Although the management of the castra peregrina is ensured by the princeps peregrinorum, it is highly probable that the official command of the frumentarii belongs to the praetorian prefect, as of every other unit in Rome ${ }^{20}$. Forty such frumentarii are attested in Rome, through inscriptions, only sixteen other being discovered in the province of origin ${ }^{21}$.

The recruitment of these principales is carried out by the provincial governor ${ }^{22}$, as they are part of his staff. It would seem that every legion sends about three such frumentarii to the provincial capital, and therefore, towards the officium consularis ${ }^{23}$. Out of these three, in most

\footnotetext{
${ }^{7}$ Durry 1968, 27.

${ }^{8}$ CIL VI 1110, Rome.

${ }^{9}$ Baillie-Reynolds 1923, 175-176.

${ }^{10}$ Baillie-Reynolds 1923, 178-179.

${ }^{11}$ CIL III 2063 = ILS 2370: Varronius... qui cucurrit frum(entarius) ann(os) XL.

${ }^{12}$ Aur. Victor, Epitomae de Caesaribus 39.44. Durry 1968, 26.

${ }^{13}$ Mann 1988, 149; Lebohec 1994, 23.

${ }^{14}$ Baillie-Reynolds 1923, 170-1.

${ }^{15}$ Domaszewski-Dobson 1967, 35; Clauss 1973, 82 (CIL VI 3341); Austin, Rankov 1995, 136.

${ }^{16}$ Domaszewski-Dobson 1967, 36, only in the $3^{\text {rd }}$ Century (CIL III 2063); Clauss 1973, 109-113; Mann 1988, 149-150.

${ }^{17}$ Clauss 1973, 85; Mann 1988, 149; Austin, Rankov 1995, 136.

${ }^{18}$ Mann 1988, 149; Austin, Rankov 1995, 136.

${ }^{19}$ Mann 1988, 149.

${ }^{20}$ SHA, Commodus, Clauss 1973, 85.

${ }^{21}$ Clauss 1973, 82, 85.

${ }^{22}$ Domaszewski-Dobson 1967, 35-36; Rankov 1990, 177 (details about their election in CIL II 4154 and XIII 8282); Austin, Rankov 1995, 136.

${ }^{23}$ The number of frumentarii from each legion is revealed by inscriptions, as CIL VI 3351 and 3362, Clauss 1973, 83. Another proof of their membership in the officium consularis is the depicting of frumentarii bearing the Benefiziarlanze, a special kind of non-functional lance, typical also to other members of this staff (beneficiarii, speculatores), on monuments, as CIL III 3241 and 5579, Rankov 1990, 181-182. Some missions of police work, mostly against the Christians, during Decius' reign, were conducted by gubernatorial mandate, according to Rankov 1990, 181.
} 
cases, two are sent to Rome, as part of their special training, in the castra peregrina ${ }^{24}$. This special kind of levy is conducted mostly from the province of origin, in which part of them return, after the completion of their special tasks ${ }^{25}$. Their stay in Rome should be regarded as a special training stage, offered by the emperor, to prepare the candidates for particular missions that they will be entrusted with ${ }^{26}$. During their stay in Rome, the approximately one hundred frumentarii are tightly bonded in personal and collegial relations ${ }^{27}$.

A large variety of missions are attested through literary or epigraphic evidence. Missions that imply police work are often mentioned, especially in literary sources. The frumentarii can arrest many types of villains, but they are detached mostly for state security matters. Espionage missions are also present amongst their duties ${ }^{28}$, and also assassinate ${ }^{29}$. In the $3^{\text {rd }} \mathrm{c}$. they must handle the provincial rebellions, and they become very unpopular in the public ey ${ }^{30}$. Inside the provincial officia, they share their duties with the speculatores and beneficiarii, and, in some cases, even with commentarienses ${ }^{31}$. Police work, in general, was entrusted to military staff, either legionary or praetorian, most of them delegated as stationarii, in many cities ${ }^{32}$. This may indicate that a statio can be considered as the headquarters of any soldiers with police tasks. Some of them have a large territory in control and, other just road stations or cities ${ }^{33}$. For those concerning a whole region, the staffs are called regionarii, or agentes $^{34}$. The whole corps of soldiers active in such a statio must have been under the command of centurion ${ }^{35}$. The frumentarii are part of this police system, many times they are detectives or executioners, called for duty together with other stationarii ${ }^{36}$.

All these police tasks are revealing them as kin to the speculatores, whose collegia they attend $^{37}$. Other missions, similar to those mentioned above, are the supervisions of large infrastructure projects. The security of marble quarries in Italy or Egypt, stone quarries in Noricum, the restoration of the Delphi site, the reparations of Salona's city walls ${ }^{38}$, or the restoration of the schola speculatorum in Aquincum ${ }^{39}$, are all projects under the custody of

\footnotetext{
${ }^{24}$ This number is approximated following epigraphic support: CIL VI 3349, 3357, 3361, Clauss 1973, 83.

${ }^{25}$ Rankov 1990, 177.

${ }^{26}$ Clauss 1973, 85.

${ }^{27}$ They call each other collegae, they raise funerary monuments for any deceased colleague, even coming from other legions (CIL VI 3332, 3334, Rome), they are promoted or released according to regular practice, but they share different careers (CIL VIII $1322=14854$, Tuccabor, VIII 2825, Lambaesis, VI 3341, 3351, Rome). Clauss 1973, 83-84.

${ }^{28}$ SHA, Hadrian 11.4-6 reveals the intercept of the private correspondence between a senator and his wife, lead by a frumentarius. Macrinus is spying on his legionaries, SHA Macrinus 12.4. Hadrian is spying on his friends, also Caracalla. Cassius Dio 78.15. Clauss 1973, 93, Austin, Rankov 1995, 136.

${ }^{29}$ SHA, Commodus 4.5 reveals a mission of political assassinate, entrusted by the emperor through the praetorian prefect. Other, such attempts to eliminate rivals, are depicted in the civil war at the end of the $2^{\text {nd }}$ century: SHA, Pesc. Niger 2.6, Iulianus 5.8, CIL X 6657 = ILS 1387, or Herodian III.5.4-5. Clauss 1973, 91, Rankov 1990, 176.

30 Aur. Victor, Epitoma de Caesaribus 39.44, Austin, Rankov 1995, 137, Clauss 1973, 104.

${ }^{31}$ CIL XIII 1771, Lugdunum, Clauss 1973, 98.

32 Plinius, Epistulae 74, CIL III 7135, 7136, Clauss 1973, 98, 100. Tertullian (Apologetics 2.8) says that such stationes hold soldiers that have to control the latrones.

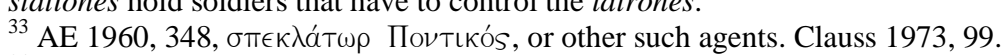

${ }^{34}$ As the case of Scantiu Lucius (AE 1957, 327), or other beneficiarii from Samum, Dacia Porolissensis.

${ }^{35}$ As in RIB 587, Ribchester, Clauss 1973, 100.

${ }^{36}$ Present especially in Christian executions. Macrinus is caught during an inspection of a coach, lead by a frumentarius (Cassius Dio 78.39.3 and Herodian 5.7-8), Clauss 1973, 101-105.

${ }^{37}$ Domaszewski-Dobson 1967, 35.

${ }^{38}$ In 170, a frumentarius leads a vexillatio for the rebuilding of these city walls, probably under the Marcomannic threat (CIL III 1980, 1973, 6374), Clauss 1973, 94.

39 As revealed by CIL III 3524. The attendance of a frumentarius to this project is probably a condition to his prospective promotion to speculator, and, eventually, to legionary centurion. A similar case is CIL III $14479=\mathrm{AE}$ 1901, 154 = IDR III/5 426, Apulum. Cupcea 2008, 272.
} 
frumentarii ${ }^{40}$. In most of these missions they are delegated by the emperor, to which they pledge their loyalty for their period of stay in the castra peregrinorum ${ }^{41}$. Their attachment to this structure is never hidden, so they must not be regarded as agents of terror ${ }^{42}$. With such activities, abuse is inevitable. Many such cases are described by sources, as standing trial and damnation with no evidence - concussio. The popular reaction is not positive to this behaviour, so, by the time of Diocletian, a thorough reform was needed, for a major image improvement. Thus came into action the agentes in rebus ${ }^{43}$.

Nevertheless, the basic duty of such an officer, as is the case with other detached soldiers, is that of messenger. It is revealed by a series of literary sources ${ }^{44}$, or epigraphic monuments ${ }^{45}$. By the time of Trajan or Hadrian, an official messengers system is established, tightly connected to the cursus publicus, which will include the frumentarii ${ }^{46}$. Their task, in this situation, is the exchange of information between the emperor and the provincial governors, or its delivery where needed ${ }^{47}$. This is maybe the reason why there are no frumentarii coming from II Parthica, garrisoned, beginning with Severus' reign, at Mons Albanus, in Italy. As it can easily be seen, most of the inhabitants of castra peregrinorum have the same main duty, that of messenger, like the speculatores, singulares or even centurions ${ }^{48}$.

For this duty to be carried out efficiently, a rigorous management of the infrastructure is needed, a connection of these special officers corps to the cursus publicus. The stationes along the main roads, or situated at important crossing points or ports, serve as headquarters for this kind of soldiers, and as control points. In Italy, such stationes, manned also with frumentarii, can be seen on Via Appia ${ }^{49}$, or in important ports, as Ostia ${ }^{50}$ or Puteoli ${ }^{51}$. These stationes can be considered different to those manned with beneficiarii, as the one in Ostia is called statio n(umeri) fr[u]mentariorum, but this is known to be a special detachment of the frumentarii corps.

At least sixteen frumentarii are known to be sent from Rome back to their legion headquarters, or to the officium consularis of their province of origin. In Hispania, frumentarii are sent from Legio to the officium consularis at Tarraco directly, along with the speculatores, commentarienses or cornicularii, apparently without their preparation stage at Rome ${ }^{52}$. Back home, they can be entrusted with several missions in provincial stationes ${ }^{53}$, along with other messengers ${ }^{54}$. In the case of these frumentarii, the issue of loyalty for the emperor is no longer

\footnotetext{
${ }^{40}$ Clauss 1973, 94-95, Rankov 1990, 177.

41 Their tight connection to the emperor is revealed by the form frumentarius Augusti, mentioned on many inscriptions (IGRR III 80 = ILS 9476, AE 1977, 60, ILS 9473, CIL XIII 1771), Mann 1988, 150, Rankov 1990, 177, Austin, Rankov 1995, 136. He is not different from frumentarius legionis, but is serving a special mission for the emperor, see Clauss 1980, passim.

${ }^{42}$ Rankov 1990, 178.

${ }^{43}$ Durry 1968, 27, Clauss 1973, 106-109, Austin, Rankov 1995, 137.

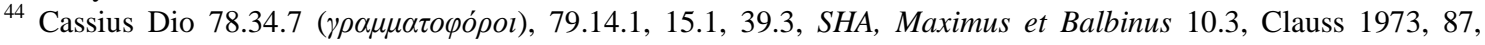
Rankov 1990, 180

${ }^{45}$ CIL III 2063, 8581 = ILS 2370, 14191, Rankov 1990, 180.

${ }^{46}$ Clauss 1973, 87-88.

${ }^{47}$ Clauss 1973, 87, Rankov 1990, 180. Empowered by the mention in CIL III 2063 = ILS 2370: Varronius... qui cucurrit frum(entarius) ann(os) XL.

${ }^{48}$ Rankov 1990, 180.

${ }^{49}$ CIL VI 230 Roma, frum(entarius) leg(ionis) XIII Gem(inae), Clauss 1973, 89.

${ }^{50}$ CIL XIV 7, 125, Clauss 1973, 82, 90.

${ }^{51}$ CIL X 1771, Clauss 1973, 90.

${ }^{52}$ CIL II 4150, 4154, 4170, 6088, Clauss 1973, 96.

${ }^{53}$ Campbell 1994, 29.

54 CIL III 3241 - Sirmium, a frumentarius holding a Benefiziarlanze, which can be considered as standard equipement for the members of officium consularis. Supra, no. 23.
} 
active, as they became officiales ${ }^{55}$. The idea of Domaszewski, that they form a special numerus frumentariorum in every provincial capital ${ }^{56}$, has not been confirmed.

Regarding military hierarchy, the frumentarius is a principalis, placed above the tactical ranks, from which it can be promoted ${ }^{57}$. His pay is double the regular pay of a soldier, this making him a duplicarius ${ }^{58}$. He is standing under the beneficiarius consularis, and it can be promoted to this rank, many beneficiarii ex frumentarii being attested ${ }^{59}$. Prospective direct promotion to centurio frumentarius, in the $3^{\text {rd }}$ century, has been assumed, but not confirmed by evidence $^{60}$. However, direct promotions to the legionary centurionate are known ${ }^{61}$, and indirect, through ranks like optio ${ }^{62}$, commentariensis or candidatus $^{63}$. Promotions to speculator are also assumed, because of their tight relation and collegiality ${ }^{64}$. Not much is known about the career of a centurio frumentarius. They are promoted inside the castra peregrinorum towards leading ranks, as subprinceps peregrinorum ${ }^{65}$, viceprinceps peregrinorum ${ }^{66}$, exercitator singularium Imperatoris $^{67}$, or, at the top of the professional career, primuspilus legionis ${ }^{68}$. In some situations, these officers' career does not end at the primipilate, in exceptional cases they can benefit from imperial favor to get to the highest ranks of praetorian prefect, praefectus Urbi, or even consul $I I^{69}$.

In Dacia, there are at least three frumentarii attested through inscriptions. However, from the legions of Dacia other four are revealed, throughout the empire, carrying various missions.

Two of the frumentarii in Dacia are mentioned on monuments in Ulpia Traiana Sarmizegetusa. Their role here remains to be determined. The other two are attested in Drobeta and Apulum, both of them standing, at the time of the erection of the monument, on higher ranks.

C. Iulius Carus ${ }^{70}$, from Sarmizegetusa, is part of a very special family, with a military tradition for ages. The inscription is graved on a honorary monument, erected in the forum of the city, in the memory of his father, a legionary veteran and city magistrate. The father, $\mathrm{C}$. Iulius Valerius, is a veteran of XIII Gemina Severiana, former beneficiarius consularis, who, after his honourable discharge, has become a member of the ordo decurionum in Sarmizegetusa, now a metropolis, and, afterwards, elected also as a IIvir of the city. He must have been financially potent and a good soldier, discharged as an officer, member of the officium consularis, all these enabling him to become a very important man for his city ${ }^{71}$. His service to Sarmizegetusa has not been forgotten, even after his death. The decurions decide to allow the erection of an honorary monument, in the forum. The veteran had three sons and two daughters that are building this monument for their father. The sons are all three soldiers, two of them

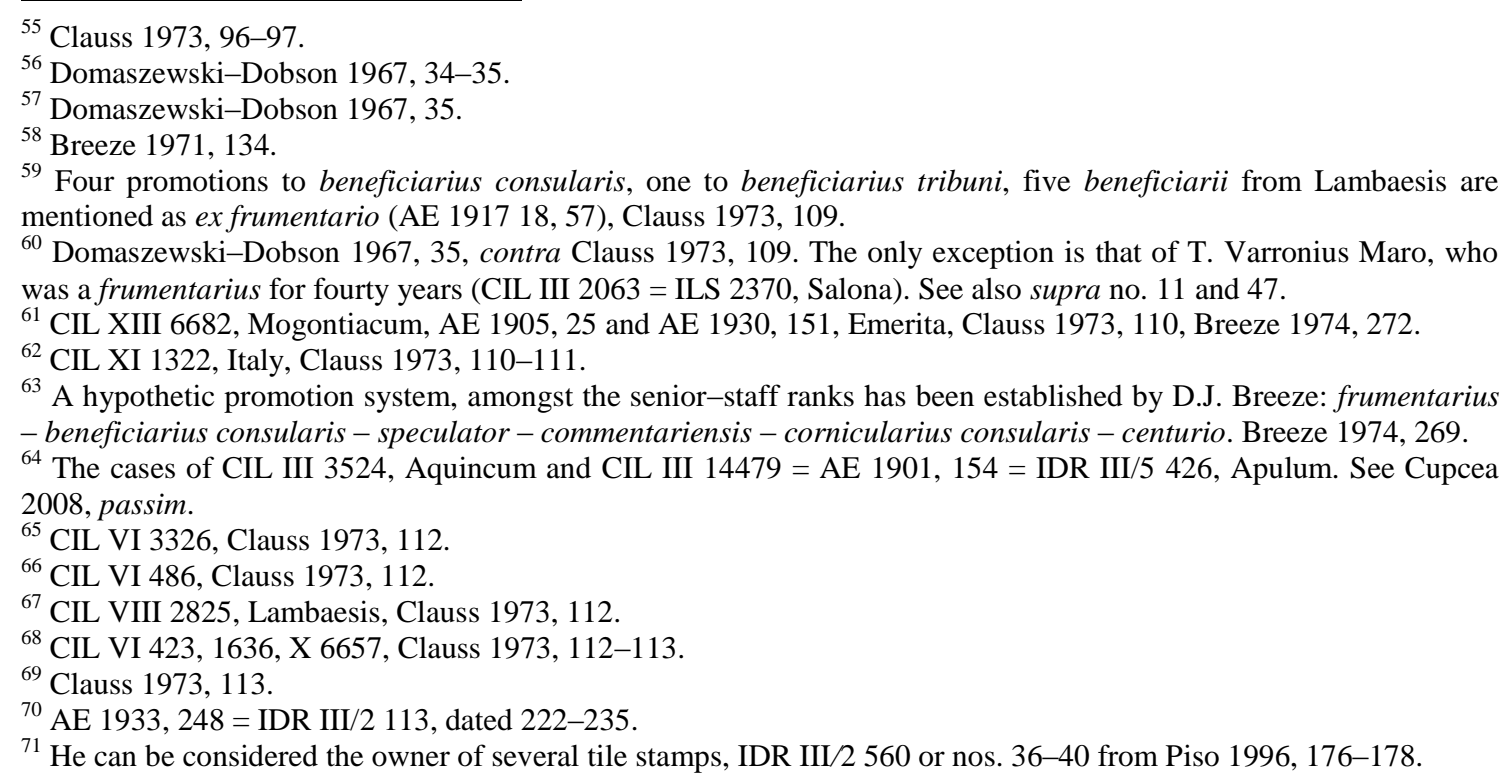


legionaries and one praetorian, all of them stand on senior-staff ranks. C. Iulius Valerianus is a beneficiarius consularis, Carus is a frumentarius and Fronto is a scriniarius praefectorum praetorio, in cohors I Praetoria. The two legionaries must have served in XIII Gemina, as their father, as no other legion is mentioned on the inscription. An interesting situation is that two of them, the frumentarius and the scriniarius, are, during their military service, also decurions. They are highly honoured by the people of Sarmizegetusa, with the grant of the decurionate in absence, a very rare and special privilege ${ }^{72}$. The curious fact is that the third son, which is a beneficiarius consularis, is not granted the decurionate, even if he is standing on the highest rank, from the three. The reason for him not being a decurion is not that of an incompatibility issue between the rank of beneficiarius and the metropolitan decurionate, but the fact that he is serving inside the province of Dacia, maybe even detached to a statio near, or in Sarmizegetusa, this not granting him any special status. The other two, must have their service in other places. The praetorian is serving in Rome, of course, as a personal archivist of the praetorian prefects. It is, therefore, highly probable that the frumentarius is also serving in Rome, or in other provinces. We have thus, a case of a frumentarius during his stage in Rome, in castra peregrinorum, serving, together with his brother, directly the emperor, in this case, Severus Alexander.

The other frumentarius from Sarmizegetusa is mentioned on a funerary monument ${ }^{73}$. P. Antonius Victor was a legionnaire in VI Victrix, garrisoned at Eburacum, in Britain, and a frumentarius, dead at the age of 19. His father, P. Antonius Super, is erecting this funerary monument, not only for him, but also for his wife, Antonia Bonosa, for Aurelius Constantius, decurion of Viminacium, eques Romanus, dead at 45, and for another son, tribune of the cohort IIII Delmatarum, dead at 34. The relation of Super to the decurion of Viminacium is not clear, maybe some distant relative of him or his wife. Anyway, the "miserable father" is probably a decurion of Sarmizegetusa, as it can be seen from another monument, a small column for the ordo augustalium ${ }^{74}$, or a tile stamp that could have been his ${ }^{75}$. Back to the frumentarius, he had been enlisted since very young in the VI Victrix legion. We don't know exactly why he had gone so far away from home, but maybe it has something to do with the origins of his family, which is, probably one of immigrants in Sarmizegetusa. His privileged status, as son of a decurion and relative to equites, probably granted him the opportunity to accede to higher ranks early on, in his military service. That is why, already at nineteen, he is a frumentarius, part of the officium of the governor of Britain, and, probably detached in some mission. If so, maybe accomplishing that mission he had lost his life, and therefore is mentioned on this monument. It is an interesting case of a colonists family coming to Sarmizegetusa, but whose young try to return to their province of origin, maybe due to relatives that remained there. Another possibility is that of transfer along with the promotion, or after the completion of the service stage in Rome, but then he must have mentioned the other legions that he served in.

The other two frumentarii in Dacia have acceded to the rank of centurion, one of them becoming even an eques Romanus. C. Titius Ianuarius ${ }^{76}$, from Drobeta, originary from Colonia Victrix - Camulodunum or Philippi, centurion of IIII Flavia, is mentioned on a funerary monument, erected by his freedman Titius Epipodius. After the mention of the legion a group of

\footnotetext{
${ }^{72}$ Ardevan 1987, 121, Piso 1993, 326.

${ }^{73}$ CIL III 1474 = IDR III/2 379.

${ }^{74} \mathrm{AE} 1933,241=$ IDR III/2 134, dated after 222, as the previous.

${ }^{75}$ IDR III/2 543, or no. 18 from Piso 1996, 166.

${ }^{7676}$ AE $1959,314=$ IDR II 35.
} 
two letters, $F R$, appears, reconstructed by the authors of IDR II as fr(umentario? $)^{77}$ A similar situation was discussed in detail by M.P. Speidel, found in several inscriptions in Lower Moesia $^{78}$. The same letter pattern is encountered in at least three inscriptions, two of them from the region of Montana ${ }^{79}$, and one from Scythia Minor ${ }^{80}$. In each of the three cases, the succession is, as it follows: name, legion (I Ital(icae) or V Mac(edonicae)), and after a single $R$. In all of the cases, the reconstruction was made to (f)r(umentarius), but Speidel had proven them all wrong. The correct reading is: (centurio) leg(ionis) I Ital(icae) r(egionarius) ${ }^{81}$. The presence of this rank is more likely than that of a frumentarius, because of the regio Montanensium, area of great economic importance, supervised by a police force of regionarii, under the command of a centurio regionarius $^{82}$. The regio Montanensium extended to the north, to the Danube and to the border with Upper Moesia ${ }^{83}$, therefore, the centurion in Drobeta must have been in a similar situation. In any case, there is more common for a centurion that mentions his legion, to be a regionarius, than a centurio frumentarius, which is written, in most of the cases by the direct succession of the two terms ${ }^{84}$. C. Titius Ianuarius has to be considered as a (centurio) leg(ionis) IIII F(laviae) f(elicis) r(egionarius), even if, maybe not the commander of the regionarii in Montana, but in any other area organized and controlled in the same manner. The mention, by a legionary centurion, of a previously held rank, especially, and only that one of frumentarius, is also not common. In my opinion, and in the light of those proven in Lower Moesia, the centurion from Drobeta must have been a regionarius, apparently deceased in the line of duty ${ }^{85}$, as a commander of a security force detached in a most important economic region.

P. Aelius Marcellus, is a very important person of Apulum and Dacia. This vir egregius is known from three honorary monuments in Apulum ${ }^{86}$ and one in Fulginiae ${ }^{87}$. The single one that is in our interest is only the third one from Apulum, a honorary marble plate. His military and civilian career is depicted here, unveiling a worthy soldier and officer. He started as a centurio frumentarius, promoted to suprinceps peregrinorum, praefectus castrorum of the VII Claudia and I Adiutrix legions, primus pilus and vir egregius. His exceptional military career led to a similar civil one, as decurion and patron of Apulum, sacerdos Laurentium Lavinatium, and patron of the cities of Fulginiae, Forum Flavinium and Iguvium. He is a standing example of a centurio frumentarius that was promoted inside the castra peregrinorum, becoming thus eligible for the primipilate and legionary prefect ${ }^{88}$. This man was an exceptional soldier, sent throughout the empire, after the completion of his service directly to the emperor, as a centurio frumentarius, to attend to command duties, and then, become an eques.

The frumentarii from the army of Dacia are attested also during various missions, throughout the empire. M. Aurelius Berulus, a frumentarius of XIII Gemina, dies during his stay in Rome, and is probably buried here, as his funerary monument attests ${ }^{89}$. He is the single

\footnotetext{
${ }^{77}$ In IDR II, other reconstructions are $F(o) r(t i s)$ or $F(i) r(m a e)$, therefore attributes of the legion, not a separate rank. Later on, C.C. Petolescu, in ILD, mentions another opinion, that a third F would have been omitted, thus the reconstruction should be leg(ionis) IIII F(laviae) f(elicis) (f)r(umentario).

${ }^{78}$ Speidel 1984, passim.

${ }^{79}$ CIL III 12371, Montana, CIL III 7420, Almus.

${ }^{80}$ AE 1980828 = ISM V 124, Horea, near Troesmis.

${ }^{81}$ Speidel 1984, passim.

${ }^{82}$ See also supra, no. 34.

${ }^{83}$ Speidel 1984, 186, proven by CIL III 7420, Almus.

${ }^{84}$ Or separated by et, as in AE 1996, $1540=$ IDRE II 411, Apamea, Syria.

${ }^{85}$ Because he is not called veteranus.

${ }^{86}$ CIL III $1181=$ IDR III/5 439, CIL III $1182=$ IDR III/5 441 and CIL III $1180=$ AE 1980, $736=$ IDR III/5 442.

${ }^{87}$ CIL XI 5215, 5216, apparently the same monument. His origo is in Apulum, because of the Papiria tribe. Dobson 1978, 319.

${ }^{88}$ Dobson 1978, 318-319.

${ }^{89}$ CIL VI 3356 = IDRE I 25, Rome.
} 
frumentarius coming from Dacia attested during his period of stay in castra peregrinorum. Another frumentarius of XIII Gemina Severiana attested in Italy is M. Aurelius Sophaenetus, this time detached for a mission in a statio on Via Appia. In this statio, himself and a colleague, Q. Haterius Valerianus, from VIII Augusta, raise an altar for the emperor Severus Alexander, the genius of castra peregrinorum and for all the army ${ }^{90}$. This is the perfect example for missions of the frumentarii which occur during their stay in Rome, cases in which they are sent, sometimes in pairs or groups, even if coming from different legions, to do any police or messenger work needed at one time in the empire.

The other two frumentarii connected in some way with the army of Dacia, but attested elsewhere in the empire, are, in fact centurions. Ti. Claudius Vibianus, centurion of XIII Gemina, is also a centurio frumentarius, detached in some mission, in Phrygia, at Augustopolis ${ }^{91}$. In this case, the second rank is a promotion from the regular legionary centurionate. The other, C. Sulgius Caecilianus, honoured by a monument in Tukabur, Africa proconsularis ${ }^{92}$, a regular vir militaris, begins his career with the post of optio peregrinorum, that is a principalis in the fort on mount Caelius, and exercitator militum frumentariorum, that is a trainer, mostly present in cavalry units ${ }^{93}$. He is then promoted to navarchus of the praetorian fleet in Misenum, then centurion of XIII Gemina in provincia Dacia. After another four legionary centurionates, he is again a praepositus in the praetorian fleet and, finally primus pilus and legionary prefect. This is the classic example of a brilliant career, beginning as principalis and ending as eques Romanus. Finally, a worthy mention is that of Aelius Verecundinus, centurion of IIII Scythica, natus in Dacia ad Vatabos $(\mathrm{sic})^{94}$, with the complete soldier career explained. His promotion system included the ranks of exactus, librarius, frumentarius, speculator, evocatus, centurio et centurio frumentarius, but, curiously, no tactical rank. Anyway, a valuable piece of information regarding the lower legionary hierarchy, even if no indication of any service stage in Dacia occurs.

The frumentarii would have been entrusted with most delicate missions, as other colleagues in the oficium consularis, or detached to castra peregrinorum. The single special feature that they have is this double subordination. Even if they are elected and promoted by the provincial governor, they are sent in Rome, to train and serve, for a determined period, in castra peregrinorum, where they activate under the direct authority of the emperor. During this special grant, they are entrusted with various missions, representing the emperor, officially or not, in remote places of the empire, and afterwards they are sent back to the province of origin, to continue their regular military service. There, they continue to be part of the officium consularis, as frumentarii, until they are either promoted or released. In this situation, they are entrusted, this time by the governor, with missions as police agents in the province, completing the work of beneficiarii or speculatores. Some of them can be promoted inside the castra peregrinorum, to higher principales ranks, or to centurio frumentarius, fact that enables them to return in their province directly as centurions. Inside the provincial armies, they are gradually promoted to beneficiarius, speculator, and, seldom, directly to the legionary centurionate. They seem to have just military tasks, different from beneficiarii or speculatores, which also have administrative and law enforcement duties. This is maybe the reason for the promotion to these ranks, so that any prospective centurion would have military and administrative training.

\footnotetext{
${ }^{90}$ CIL VI $230=36748=$ ILS 2216.

${ }^{91}$ CIL III $7041=13654=$ IDRE II 385. For a list of centurions of XIII Gemina, attested in other provinces, in the $2^{\text {nd }}$ or $3^{\text {rd }}$ centuries, see Moga $1985,102$.

${ }^{92}$ CIL VIII $1322=14854=$ AE 1956, $11=$ IDRE II 431.

${ }^{93}$ Indication towards the mounted state of the frumentarii, most of them messengers.

${ }^{94}$ AE 1996, 1540 = IDRE II 411, Apamea, Syria.
} 
The persons mentioned above, connected in some way or the other to the army of Dacia, are attested in different stages of their career. Four of them are simply frumentarii, mentioning their legion of origin. For the three of them we know that they come from XIII Gemina, and all seem to be attested during a remote mission. C. Iulius Carus from Sarmizegetusa is probably serving his stage in Rome or entrusted with some mission, as him and his praetorian brother are honoured with the metropolitan decurionate in absence. Another, M. Aurelius Berulus, dies during his detachment to Rome, so he is buried here, by his colleagues, with the mention of his legion, on the monument. In the case of M. Aurelius Sophaenetus, we know exactly the mission, that is the supervision of a road station on the Via Appia, known to be manned with frumentarii, along with a colleague from VIII Augusta. The second frumentarius attested in Sarmizegetusa is known from a collective funerary monument that tells us about his service at Eburacum, in the VI Victrix legion, dead in the time of duty, at the age of 19 . He seems to have been either serving in the officium consularis of Britain, and there he had lost his life, or being detached with any mission in Dacia, closer to the home of his parents. In any case, his perspectives would have been promising, as he was a frumentarius already at 19.

The other five examples mentioned in this paper are all centurions, with some connections to the rank in discussion. C. Titius Ianuarius, from Drobeta, thought to be a centurion of IIII Flavia and frumentarius, has been proven to be regionarius, as many other colleagues of his in Lower Moesia, fact that doesn`t make him any less important. A very important person of Apulum, P. Aelius Marcellus, depicts his exceptional career, beginning with the rank of centurio frumentarius and ending as eques and patron of more than one city. Another similar career is that of C. Sulgius Caecilianus from Africa, which, beginning with the rank of optio peregrinorum, spent a stage of his military service in Dacia as a centurion of XIII Gemina. Finally, Ti. Claudius Vibianus, centurion of XIII Gemina and centurio frumentarius is attested probably during a mission in Phrygia. A worthy soldier, that reaches the peregrine and legionary centurionate, is born in Dacia, Aelius Verecundinus.

What can be said about these soldiers` missions in Dacia or any other limes province? There are no special missions for the limes area. The frumentarii are active in any place of some importance to the proper functioning of the economic and administrative apparatus, not only on the borders. As part of the officium consularis, they can be detached in the limes zone, to do the police work there ${ }^{95}$, but this is not more or less important that their work inside the empire's territory. They are very important agents of the Roman authority, representing the emperor in any situation, even if considered "dirty work". Their special training in Rome enables them to accomplish any security mission, to control the road traffic or information. Therefore, the frumentarii of Dacia have no special mission in their province of origin, except maybe of those regular missions entrusted with by their governor. Moreover, they seem to have been elected for missions across other provinces, as Asia or Italy. In this case, we must presume that frumentarii coming from other legions would have been detached with missions in Dacia, as to ensure the correct accomplishment of their duty, free from any connection with a former commander or colleague. Good for anything, the frumentarii are as important as any other military for the proper function of the Roman state.

\footnotetext{
${ }^{95}$ As are the beneficiarii in the region Ansamensium, Northern Dacia.
} 


\section{BIBLIOGRAPHY}

Ardevan 1987 - R. Ardevan, Veterani şi decurioni municipali în Dacia romană, Sargetia 20, 117-126.

Austin, Rankov 1995 - N. J. E. Austin, N.B. Rankov, Exploratio. Military and Political Intelligence in the Roman World from the Second Punic War to the Battle of Adrianople, London-New York.

Baillie-Reynolds 1923 - P. K. Baillie-Reynolds, The troops quartered in the castra peregrinorum, JRS 13, 168-189.

Baillie Reynolds, Ashby 1923 - P. K. Baillie Reynolds, T. Ashby, Castra peregrinorum, JRS 13, 152-167.

Breeze 1971 - D. J. Breeze, Pay Grades and Ranks below the Centurionate, JRS 61, 130-135.

Breeze 1974 - D. J. Breeze, The Organization of the Career Structure of the immunes and principales of the Roman Army, BJ 174, 245-292.

Campbell 1994 - B. Campbell, The Roman Army 31 BC - AD 337. A Sourcebook, London-New York.

Clauss 1973 - M. Clauss, Untersuchungen zu den Principales de römischen Heeres von Augustus bis Diokletian. Cornicularii, speculatores, frumentarii, Diss., Bochum.

Clauss 1980 - M. Clauss, Frumentarius Augusti, Epigraphica 42, 131-134.

Cupcea 2008 - G. Cupcea, Speculatores in Dacia. Missions and careers, ActaMN 43-44, I, 263-279.

Domaszewski-Dobson 1967 - A. von Domaszewski, Die Rangordnung des römischen Heeres ${ }^{2}$ (ed. B. Dobson), Köln-Graz.

Dobson 1978 - B. Dobson, Die primipilares, Köln.

Durry 1968 - M. Durry, Les cohortes prétoriennes, Paris.

LeBohec 1994 - Y. LeBohec, The Imperial Roman Army, London.

Mann 1988 - J.C. Mann, The Organization of the frumentarii, ZPE 74, 149-150.

Moga 1985 - V. Moga, Din istoria militară a Daciei romane. Legiunea XIII Gemina, Cluj-Napoca.

Piso 1993 - I. Piso, Die soziale und ethnische Zusammensetzung der Bevölkerung in Sarmizegetusa und in Apulum, Prosopographie und Sozialgeschichte. Studien zur Methodik und Erkenntnismöglichkeit der kaiserzeitlichen Prosopographie. Kolloquium Köln (ed. W. Eck), Köln-Wien-Weimar, 315-337.

Piso 1996 - I. Piso, Les estampilles tégulaires de Sarmizegetusa, EN 6, 153-199.

Rankov 1990 - N.B. Rankov, Frumentarii, the castra peregrina and the Provincial officia, ZPE 80, 176-182. Speidel 1984 - M.P. Speidel, Regionarii in Lower Moesia, ZPE 57, 185-188. 